\title{
Implementing and Operationalising Integrative Approaches to Sustainability in Higher Education: the role of project-oriented learning
}

Walter Leal Filho

School of Sciences and the Environment, Manchester Metropolitan University, Chester Street, Manchester M1 5GD, UK

E-mail:w.leal@mmu.ac.uk

Chris Shiel, Faculty of Science and Technology, Bournemouth University, Dorset, BH12 5BB UK

Email: cshiel@bournemouth.ac.uk

Arminda do Paço, University of Beira Interior, Department of Business and Economics

Estrada do Sineiro, s/n, 6200-209 Covilhã, Portugal

E-mail:apaco@ubi.pt

\section{Abstract}

Higher education institutions across the world are increasingly placing an emphasis on students' acquisition of a broader range of skills or attributes within the taught curriculum, which should lead to a widening of their chances of academic success, in particular in the employment market. Among other issues, matters related to sustainable development are playing a key role, but many universities do not yet cater for integrative approaches, which may help them to approach sustainability issues in a transformative way. It is therefore necessary to develop new approaches and methods, which may address this gap. Based on the importance of meeting this perceived research need, this paper defines the role of project-oriented learning, also designated as Project Based Learning, as a tool to support integrative approaches to sustainability in a higher education context. The scientific value of the paper lies in the provision of some examples of successful approaches to Project Based Learning and the identification of some of the trends that characterise it. The paper makes clear why project-oriented learning should be more widely used in support of integrative approaches to sustainability, and why it needs to become part of the routine of higher 
education institutions. The outline of some of the initiatives recently and currently being undertaken may inspire others and assist in the implementation of Project Based Learning.

Key-words: Project Based Learning; Project-oriented learning; Sustainability; Higher education; Integrative curriculum. 


\section{Introduction}

Since the 1990s, in response to challenges from industry that graduates were not 'workready', universities have increasingly focused their attention on developing graduates who are employable; finding ways to identify and embed the most appropriate employability skills within the curriculum has been an on-going concern. In 2015, employability remains high on both the educational and political agendas: universities need to demonstrate that their courses lead to more attractive recruitment opportunities for students; governments need to ensure that sufficient human capital is developed to compete in a global marketplace. This has been particularly significant in the UK, where employability statistics, formally collected through the Higher Education Statistics Agency (HESA), contribute to league tables, and where the Higher Education Funding Council for England (HEFCE), emphasises:

"Embedding employability into the core of higher education will continue to be a key priority of Government, universities and colleges, and employers. This will bring significant private and public benefit, demonstrating higher education's broader role in contributing to economic growth as well as its vital role in social and cultural development" (HEFCE, 2011, p.5).

It is now generally accepted within higher education that 'employability' means the development of: "a set of achievements - skills, understandings and personal attributes that make graduates more likely to gain employment and be successful in their chosen occupations, which benefits themselves, the workforce, the community and the economy" (Yorke, 2006, p.8).

Research has explored: how to enhance employability (Harvey et al., 2002); career development (Kumar, 2007), ways to embed employability within the curriculum through a 'pedagogy for employability' (Pegg et.al, 2012), and ways to assess employability (Knight and Yorke, 2003). Very little research has explored the link between employability and sustainable development with the exception of a few studies such as, Shiel et al. (2005) (in one of the first studies to make a link between sustainable development, employability and internationalisation) and work to develop the concept of global citizenship (Bourn and Shiel, 2009) where it is suggested that developing graduates as global citizens who understand the need for sustainable development would contribute not only to employment but more importantly, to enhancing society and achieving sustainable development. Stibbe (2009) implicitly suggests the link between employability (understanding and attributes) by suggesting the development of 'sustainability literacy' which would enable graduates to better address what has largely been unsustainable development. 
This paper aims to extend the link between employability and sustainable development by referring particularly to integrative approaches to sustainable development and suggesting how Project-Based Learning (PBL), an approach used in contexts as varied as non-formal and informal workplace learning (Kyndt et al., 2009), or nursing and medical education (Feletti, 1993) may enhance learning and development. Research suggests that the experience of project work and problem-based learning supports the development of personal skills (Kolmos, 1996) and abilities (Moesby, 2005); the skills that are required and honed as part of PBL, are skills that enhance employability prospects. In this paper it will be suggested that approaches associated with PBL not only contribute to the development of employability skills, but may also enable universities to work in a more synergistic way, where the curriculum, the extra-curricular and the co-curricular enhance the experience of the learner through a focus on sustainable development. The paper will first consider the relevance of sustainability in the curriculum and how this might enhance employability before discussing the need for integrative approaches. The role of PBL will then be considered and examples will be provided of where PBL has been used to take forward sustainability projects, before lessons learned are presented and conclusions are drawn.

\section{Sustainability in the curriculum: its relevance in enhancing employment prospects}

The concept of sustainable development has gained significant attention since the Brundtland Report. According to Gandhi et al. (2006), sustainable development is defined as the development that meets the needs of the present generation without compromising the ability of future generations. However, lack of understanding and/or poor interpretation of this definition may have served, at least initially, as a barrier to the implementation of sustainable practices within Higher Education. Nevertheless, the role that universities have to play in relation to sustainable development, through education and developing the competences that will contribute towards a more sustainable future (Barth and Reickman, 2012) is quite clear (Cortese, 2003; Gough and Scott, 2007). Universities should act as agents of change through promoting the principles of sustainable development within their institutions and in society.

One of the changes that occurred in higher education provision in the 1990's, was the incorporation of greater environmental awareness into undergraduate and post graduate level courses. These adjustments, regarded by many as an innovation, were seen as a good way of preparing students for the new world of work, where business would need to be more sustainable. For some students, developing a deep knowledge of the science, technology 
and design skills, implicit in sustainability education, suggested greater potential for employment prospects than traditional courses. Sustainability education has often tended to involve students in practical activities such as campus greening initiatives, field visits to learn about and develop sustainable practices, and environmental studies courses or workshops. Education for Sustainability (EfS) in higher education has continued to evolve; it is suggested that EfS prepares future professionals to be responsible citizens in a more sustainable society (Biedenweg et al., 2013).

According to Pearson et al. (2005), HEls have an important role to play in society by incorporating EfS within the curriculum and promoting the sustainability debate across communities. Pearson et al. suggest that the impacts from "research and development of technology and human systems that work towards sustainability; training technicians in monitoring targets and detection of sustainability thresholds; and giving graduates the skills, knowledge and attitudes to make a sustainability contribution" (p.178), will be clearly noticed.

However, the amplitude of the challenge of integrating sustainability into higher education is significant (Springett, 2005); curriculum transformation depends upon the expertise and ability of faculties who conceive course outlines. They need to develop academic programmes that integrate sustainability and ensure that students develop the knowledge, values and competences to enable them to work with others to enhance the social and natural environment.

In the main, the curriculum across most universities is developed to provide students with an increasingly narrow understanding of courses, professions and jobs, with a focus on specific knowledge and skills. A curriculum embracing education for sustainability requires a broader approach than just discipline knowledge. It should prepare learners for living sustainably, both in the personal and professional spheres, and enable the student to develop a profound understanding of the interactions and consequences of actions and decisions (Barth and Reickman, 2012). According to AASHE (2010), students need to learn and practice holistic systems thinking and be able to apply such thinking to real world situations. Moreover, students must understand how the social, economic, and natural systems function and are integrated. The inclusion of sustainability in the curriculum in this way will also be advantageous for graduates, as they are better prepared for employment. Boutou (2013, p. 31) confirms this in his university curricula comparative study: "this practice is the best kick start for future professionals in sustainable development because graduates from the other programs have more difficulties in finding their first internship on their own". 
Alshuwaikhat and Abubakar (2008) suggest that as universities prepare the world's future leaders, entrepreneurs, and decision makers, the way they prepare learners for employability in the context of a need for sustainable development, is also crucial. Apart from communicating the significance of sustainability, knowledge of environmental preservation, economic empowerment, gender equality, good governance, health and safety, and other social and economic issues should also be addressed. Where sustainability is embedded into graduate and undergraduate courses and curriculum across areas of knowledge, it should enhance employment prospects and contribute to sustainable development more widely.

In order to address the challenges that HEls are facing in embedding education for sustainable development, and to meet the expectations of students to learn about sustainability, Leal Filho et al.(2015) suggest that universities should support teaching staff and provide some flexibility to develop formal and extra-curricular resources for sustainability and employability skills relevant to their courses. They should also work with employers and entrepreneurs to identify the capacities and knowledge needed for business opportunities in the green economy. In turn policy makers should provide guidance to ensure that learning and teaching resources on employability incorporate the issue of sustainability.

In conclusion it is possible to affirm that the implementation of sustainability in the curriculum can bring economic (employment opportunities), environmental (sustainable resource usage) and social (a better quality of life) consequences that go beyond the students' life in the university campus. Further, the essence of career development must adapt to fluctuating global demands where effective sustainable development is now a priority, not an option.

\section{The need for integrative approaches}

Sterling and Thomas (2006) suggest that the curriculum requires more than the mere addition of content and that education for sustainability should not be viewed as one more subject to be added to that curriculum. Instead, the focus should be on a wholly integrative approach where sustainability is considered as a context for delivering the objectives of education and not as a competing priority. Additionally, Sterling (2004) states that the major learning challenge for higher education in the shift towards a more sustainable society is not just in terms of student education but also in supporting learning with relevant stakeholders and within wider society. 
It is expected that a university that promotes sustainability in its curriculum has a clear vision of sustainable development and the commitment of management to sustainability. However the integration of different approaches is not always easy. Pearson et al. (2014), illustrating their own experience at the University of Newcastle, suggest that there is an enormous tension between the logic of integrative environmental education, existing curriculum elements, staff assignments, course specialisation, university political and programme design. "Environmental science and management problems are generally thought to be interdisciplinary or transdisciplinary and so various disciplines are needed in the delivery of education. This is complex because the discipline structures are the resource foraging and reallocation units (silos) so they are in competition" (p. 179). Nevertheless integrative approaches in the curriculum are useful and necessary.

The difficulty in pursuing integrative approaches in curriculum is also evident in the following example: academics are engaged in environmental and sustainability research across the university but not necessarily in a co-ordinated way. Thus, there is a challenge of implementing interdisciplinary approaches to both research and education in universities (Wade and Stone, 2010). Other related problems are the lack of resources to support interdisciplinary working, lack of supportive academic reward systems, contrasting discipline cultures, departmental policies and procedures (Leal Filho et al., 2015).

In their study Leal Filho et al. (2015) concluded that integrative approaches to sustainable development are not only needed with a view to consolidating the potential contribution of each institution, but that they are also effective. However it is hard to say whether there is a right approach, or to conclude that an integrative approach has been fully achieved. Table 1 illustrates some of the characteristics that integrative approaches should have.

Table 1. Characteristics of integrative approaches to sustainable development

\begin{tabular}{ll}
\hline \multicolumn{1}{c}{ Element } & \multicolumn{1}{c}{ Characteristic } \\
\hline Commitment & $\begin{array}{l}\text { Environmental, social and economic issues are considered } \\
\text { Knowledge }\end{array}$ \\
issues pertaining sustainability & $\begin{array}{l}\text { Wide range of options towards a more systematic sustainable } \\
\text { development }\end{array}$ \\
Diversification & $\begin{array}{l}\text { Continuous monitoring of problems or weaknesses ;implementation } \\
\text { of adjustments and corrections when necessary }\end{array}$ \\
Communication & Improvement of communication among experts and stakeholders \\
\hline
\end{tabular}


It is evident that universities have a key role to play as agents of change; particularly those who adopt an integrative approach to sustainable development that embraces curriculum, campus (Brinkhurst et al., 2011), community and research are likely to make a more effective contribution. Such an approach is more likely to have impact, if training and development opportunities for academic staff are supported (Barth and Rieckmann, 2012), a participatory approach is implemented (Disterheft et al., 2015) and social learning methods are used (Dlouhá et al., 2013).

In an integrative vision, sustainability principles are better articulated if there is a more pronounced focus on inputs from various academic disciplines (as opposed to a monodisciplinary emphasis), inter-disciplinarity is more consistent with the goals of EfS (Krizek et al., 2012). However, despite the recognisable need to develop more holistic approaches to sustainability, comparatively few universities have so far successfully embedded education for sustainable development across the entire curriculum (Shiel and Paço, 2012). There is however, an increasing trend towards integrating sustainability as a transversal theme that impacts on all students, rather than limiting it to specific parts of the curriculum but achieving such outcomes remains a major challenge. In sum, integrative approaches in higher education are useful and have the potential to enhance the student experience and optimise employability prospects; they are necessary to enable universities to fulfil their leadership role in identifying coherent and suitable solutions for a better future, in environmental, social and economic terms.

\section{Method: reflecting on the role of PBL}

The aim of this paper is to explore the role of Project Based Learning, and to discuss how the pedagogic philosophy behind it, not only enables learners to deploy and enhance the skills that are required for employability but also, fosters awareness of sustainable development by means of a problem solving approach (Pavelich. 1995). It also the intention to explore how the process-oriented learning behind PBL (Ebner et al., 2010) may support integrative approaches to sustainability (where curriculum, campus, research and community are interrelated).

There were three stages to data gathering, which led to this paper: firstly, secondary research enabled anunderstanding of the concept and the processes used in PBL to support the identification of potential examples; an analysis of documented case studies followed, with a view to collating a range of projects, and finally; following up through personal 
contacts, some of the schemes that were identified as potential examples to demonstrate the various uses of PBL, were explored further.

In respect of the methods used, it should be pointed out that the paper aims to offer a selection of illustrative examples, among the many available. Examples were selected based on the availability of information, where the experiences were documented, and where there was access to the data sets. The intention was to select examples to illustrate different angles, mini "descriptive case studies" (Scapens, 1990) rather than undertake rich, casestudy research, in the sense used by Yin (1994) of just one or two. The goal was to address a gap in studies, where the various skills derived from PBL are outlined but approaches are not often linked to the context of sustainable development. The data gathered in the study provides, a basis upon which further analysis of the links between PBL, sustainability and employability can be extended subsequently.

Before the examples are presented, the potential of PBL will be outline in the next section.

\section{PBL - learning by doing}

It is widely acknowledged that we live in a rapidly changing world, where technological innovations set new requirements for the current education system that, in turn, lead to a continuous transformation in teaching and learning methods. In pursuit of these changes, the European Higher Education Area (EHEA) proposed a new model that focuses on the shift of an education system based solely on teaching, to a system based on active learning and making the student the centre of the educational process (Rodriguez et al., 2015). This change of student role has developed from the recognition that traditional instruction does not prepare students for the changing face of today's workforce and society (Ravitz, 2008).

It is important to note that the instructional method centred on the learner is hardly new. The approach of "learning by doing" has been already advocated. For instance, John Dewey in 1916, cited by Fernandes (2014), argued that students must be at the centre of the learning process and that they should develop skills that prepare them for the future. According to Dewey, the role of the educator is to facilitate the learning process, guiding the student as he/she progressively develops as an independent learner.

Project Based Learning (PBL) is an approach where learning principles are aligned with John Dewey's educational ideas (Fernandes, 2014). In this case the problem serves as a stimulus for students to identify what they need to learn to understand or solve the problem, 
searching for an adequate solution and basing their decisions on evidence (Klegeris and Hurren, 2011). PBL is a dynamic approach to teaching, in which students explore complex real-world problems and challenges, simultaneously developing cross-curriculum skills while working in small collaborative groups (Edutopia, 2008). It is a student-driven, teacherfacilitated approach to learning (Bell, 2010), based on imagination, planning and fictionalising (Tascı, 2015). Students build up and direct their own learning, develop their creativity, solve problems they face cooperatively (Ergül and Kargın, 2014), and learn to perform tasks as varied as the design of experiments, the making of predictions, undertaking observations, and also preferring explanations related to the veracity of their predictions (Hmelo-Silver, 2004).

Project Based Learning teaches a multitude of strategies, which are critical for student's success (Bell, 2010). The core idea of the approach is to link theory to practice by solving real life problems related to students' future professional contexts (Fernandes, 2014). Learners are encouraged to take responsibility for their learning experience and to shift from passive to more active learning patterns (Hadim and Esche, 2002). They build their own knowledge and produce tangible outcomes (Gültekin, 2005) while also developing skills that are important for employability (see for example, York and Knight 2006).

According to Rodriguez et al. (2015), the PLB methodology emphasises activities which are: long-term, student-centred, based on collaborative team learning and integrated with real world practices. The approach achieves productive outcomes, and the development of skills, such as self-management, teamwork, leadership, time management, communication and problem-solving and the ability to use technology-based tools.

A project-based learning approach is characterised by organising around an open-ended question or challenge, creating a need to know essential content and skills, and incorporating processes for feedback and revision. In addition, it requires critical thinking, problem solving, collaboration and various forms of communication as well as inquiry, with a view to learning and/or creating something new (Institute for Teaching and and Learning Innovation of the University of Queensland 2015).

\section{Concept}

PBL is a pedagogic approach that organises learning around projects (Rodriguez et al., 2015). The project is considered as a tool that emphasises the process aspect of learning (Tascı, 2015). Projects are complex tasks, based on challenging questions or problems, that involve students in design, problem-solving, decision making, or investigative activities 
(Thomas, 2000). In addition, projects provide students with the opportunity to bring together knowledge-based skills such as key concepts, principles and theoretical models from a number of different subject areas and apply these to real life problems (Centre for Teaching Excellence of the Singapore Management University, 2015). As an approach PBL lends itself to addressing the complex issues involved in seeking more sustainable development while at the same time providing a valuable opportunity for participants to develop employability skills.

Regarding the steps in the PBL process, usually, students analyse a problem as a group and identify and integrate the shared background knowledge of the problem. Then the group discusses possible solutions based on the available knowledge and information and decides what additional information is needed to solve the problem. These ideas are successively refined and each group member is motivated to find and share the information. This process includes the following steps: understand the situation/clarify terminology; identify the problem; suggest possible causes; associate problems and causes; decide what type of information is needed; obtain information; and apply the information (Wood, 2003).

However, there are no commonly shared criteria for what constitutes an acceptable project, suitable for PBL. This is because projects vary greatly in their scope, depth of the questions explored, the clarity of the learning goals, the content and structure of the activity, and guidance from the teacher. Typical projects present a problem to solve, a phenomenon to investigate, a model to design, or a decision to make. Projects can guide the entire curriculum or simply comprise a few scattered hands-on activities. They might be multidisciplinary or single-subject (David, 2008). In a useful review Thomas (2000) lists the following characteristics of PBL projects:

- projects are central, not peripheral to the curriculum;

- projects are focused on questions or problems that drive students to encounter the central concepts and principles of a discipline;

- projects involve students in a constructive investigation;

- projects are student driven to some significant degree;

- projects are realistic.

The relevance of project topics stimulates students' enthusiasm and motivates them to take an active interest in their own learning process rather than mainly focusing on obtaining a satisfactory grade (Hadim and Esche, 2002). 


\section{Role of the teacher}

The teacher plays the role of facilitator, working with students to frame worthwhile questions, structuring meaningful tasks, coaching both knowledge development and social skills, and carefully assessing what students have learned from the experience (David, 2008; Efstratia, 2014). Teachers oversee each step of the process and approve each choice before the student embarks in a direction (Bell, 2010).

As opposed to conventional methods of students' assessments, during PBL, there are various separate stages where evaluation and assessment may be performed, including activities, workshops, labs, and researches with several assessments before the final evaluation. Such structure allows teachers to be more objective but also to enable their students to achieve better learning outcomes. In addition, in comparison to the traditional teaching method that evaluates only cognitive skills, PBL evaluates cognitive and emotional - social skills (Efstratia, 2014).

\section{Benefits of PBL}

The findings of various studies focused on the assessment of project-based learning approaches, demonstrate a variety of benefits that result from using PBL in comparison to other learning approaches. PBL motivates learners to obtain deeper knowledge of the subjects being studied, helps students develop confidence, self-direction, organisational and project management skills, team-building and research skills (Edutopia, 2008; Hadim and Esche, 2002), and enhances their communication skills. The approach addresses a wider set of learning styles and promotes critical and proactive thinking (Hadim and Esche, 2002).

The results of a British study (Boaler, 1999) that compared groups of students who were taught using traditional and PBL math programs over the course of three years, showed that three times as many PBL students achieved the highest possible grade in the national exam, than the students at a traditional school (Bell, 2010).

Further, the findings of research conducted in the Eskiflehir Sehit Ali Gaffar Okkan Primary School (Turkey) demonstrate that a project-based learning approach improves academic success, makes learning enjoyable, meaningful and permanent, and develops essential and important skills in students (Gültekin, 2005). Another study conducted in Karatli Sehit Sahin Yilmaz Elementary School, Nigde (Turkey), revealed that the students who were educated usingproject-based learning methods were more successful and had higher motivation levels, than the students who were educated using traditional instruction methods (Baş and Beyhan, 2010). 
In addition, the PBL approach provides opportunities for students and teachers to use technology to find resources and information, create products, as well to collaborate more effectively, and connect with experts, partners, and audiences around the world (Buck Institute for Education (BIE), 2015). Such skills are certainly those required for employment in a global context.

Further, PBL enhances professional communication across cultures, developing specialists with higher tolerance levels, who are ready to live and work in a multicultural society. The study conducted at the Zabaikalsky State University (Russia) reported that PBL used in international student groups, generates high levels of respect and self-acceptance, combined with greater tolerance towards a different national culture (Voronchenko et al., 2015).

The findings of a study that investigated the use of PBL within the context of a first year engineering degree, at the University of Minho (Portugal), indicated that the approach fosters deep-level learning and important skills for professional practice, as the development of the project provides a real life context for linking theory to practice. Students are able to relate their work to broader professional situations outside the academic world. Another positive aspect of PBL is teamwork, where students have the opportunity for students to develop transferable skills, such as problem solving, time management, oral and written communication skills (Fernandes, 2014).

\section{Challenges and Limitations of PBL}

Like all teaching methods, PBL also has some negative implications criticisms. Firstly, there is some evidence that suggests that one of the main constraints of the approach, is that some students find the workload too heavy. In addition, they (students) argue that the effort put in to the project is not always equally shared by all team members; as a result, many prefer traditional teaching and assessment methods, in which they play a more passive role in the learning process (Fernandes, 2014).

According to a study that analysed lecturers' personal experience of using PBL, in the Lithuanian University of Educational Sciences, lecturers pointed out that the gap, between expectations of students and those of the lecturer, is an undeniable justification for PBL to fail. In their study, lecturers saw the student as playing a central and independent role in PBL, whereas students were more dependent and expected greater communication and support. They also noted that some students tended to shift the responsibility for the quality of studying and project implementation to the group, to avoid assuming individual 
responsibility for the outcome of activities of the whole project group (Lasauskiene and Rauduvaite, 2015).

Some teachers are also discouraged from implementing PBL. Among the reasons are, lack of training, experience, and motivation, or considering PBL as an additional onerous activity (Efstratia, 2014). The preparation and implementation of PBL requires a great deal more work than the preparation and delivery of traditional courses (Rodriguez et al., 2015). In the USA, public high school teachers indicated a lack of time for such activities (Ravitz, 2008). PBL takes more time to plan (i.e. curriculum alignment), more academic and technology resources, more day-to-day problem solving about how to scaffold student growth and success in their project work, and more effort to authentically assess student learning (Lee et al., 2014) and what is more important, to venture into new territory that requires a background that is not always fully developed in academia (Rodriguez et al., 2015). Furthermore, teachers have to overcome challenges such as deficient financial and technological support (Efstratia, 2014). Without carefully designed tasks, skilled teachers, and school conditions that support projects, project-based learning can easily devolve into a string of activities, with no clear purpose or outcome (David, 2008).

Another challenge of implementing a PBL approach, is that clear guidance on the best approach is not clearly articulated: the diversity of defining features coupled with the lack of a universally accepted model or theory of $\mathrm{PBL}$, has resulted in a great variety of PBL research and development activities (Thomas, 2000).

The next section of this paper will now provide illustrative examples of how a PBL approach has facilitated sustainability projects.

\section{Examples of project oriented learning on sustainable development}

One of the means to foster PBL is by the use of project oriented learning, here defined as, the specific use of projects as learning tools, via which the aim of project based learning can be achieved. This, in turn, can lead to improved skills among those involved. In the specific case of students, the set of abilities deriving from project based learning can improve their employment prospects (Bell, 2010). The case studies that are now presented represent a variety of projects that have used these methods.

The grounding of the results described in this section, is based on four scientific principles. Firstly, the principle of evidence based findings, a result of the analysis of each case study. Secondly, the study caters for a comparison among contexts and settings, offering a clear 
view of the variety of ways PBL may be used. Thirdly, the research is internationally oriented, serving the purpose to show that PBL may be put into practice in different country contexts. Finally, the grounding of the results here presented is also based on the principle of replicability, meaning that each of the case studies documented may be replicable elsewhere.

\subsection{The TESS course}

The first example relates directly to the development of students providing an illustration of PBL in the international context of sustainability and a global economy. The Time European Summer School (TESS) represents a truly European learning experience.

The TESS course, an innovative international learning experience, has been developed by European and non-European universities such as KTH (Stockholm), BUTE (Budapest), ITU (Istanbul), SUPELEC (Paris), UNITN (Trento), UPM (Madrid) to teach a common course in an unconventional, remote way, to geographically-separate groups of students. The course has already been running for last six years with success, as demonstrated by means of an evaluation report recently produced. It is operated with the support of the T.I.M.E. (Top Industrial Managers for Europe) Association and the European Commission's DG Education and Culture, through the Erasmus Lifelong Learning Programme.

Based on this experience the partner universities propose a new and unique pedagogical approach for the benefit of the students. The approach aims to present students with the challenge of proposing solutions to real problems in a global context, using PBL methodology. In addition, it works to strengthen of students' transversal competences. Developed projects will relate to, for example, such topics as the global economic system; sustainable development; limited natural resources; climate change; clean tech; energy in a global context; etc.

This course allows students to develop a deeper knowledge of global issues and to strengthen competences such as critical thinking, problem solving, collaboration and communication. The students are in constant communication with the lecturers, irrespective of where they are located, and with their fellow students at the other campuses. Lectures, discussions and presentations are held between the campuses of the partners universities via the Internet in real time (Marcos et al., 2015; T.I.M.E European Summer School Consortium, 2015). Thus it can be concluded that PBL can be used as a means to foster 
sustainability issues as part of the curriculum; a limitation of this approach is the costs involved, as such mobility schemes demand external funding.

\subsection{The Industrial Engineering and Management (IEM) degree of the University of Minho}

The Production and Systems Engineering Department of the University of Minho has a decade of experience in promoting the PBL methodology in the M.Sc. degree in Industrial Engineering and Management (IEM). The PBL method is applied to IEM freshmen right from the first semester, and widely explores teamwork and interdisciplinary learning by addressing semester-wide projects.

Students are normally divided into teams. The teams remain the same throughout the semester, while a tutor monitors the progress towards an original solution for the proposed challenge. Each team is expected to interact with all teachers and the remaining teams on several occasions, namely through public presentations, reports, the extended tutorial and the prototype demo.

Since industrial practice is increasingly tied-up with and driven by, a sustainability agenda, the themes of the projects are carefully selected to introduce issues related to sustainability. The aim is to motivate students to actively pursue information, develop their knowledge and proactively design product and system solutions that are environmentally sound, promote social equity and improve value, while minimizing resource use and waste generation. Examples of the PBL developed themes include:

- Specification of a fuel cells production system;

- Desalination of sea water;

- Production of batteries for an electric car: specification of the battery and its production system ;

- Use of organic waste for the production of bio-alcohol;

- Air2Water: specification of a portable device for production of drinking water from air humidity;

- Clean-up and recovery of crude oil from sea spills;

- Specification of a disassembly line for recycling of WEEE (waste electrical and electronic equipment) and

- Design of a more sustainable packaging and specification of the production system. 
However, it is important to note that the assessment of the final results has shown that although the project was clearly directed towards the development of more sustainable products and cleaner production systems, the project's themes, their diversity and the depth of the taken approaches were not exactly aligned with the expected learning outcomes for some aspects of sustainability introduced in the curricular units. The lesson to be learned in this particular case, is that a PBL approach needs to be more closely aligned with the expected learning outcomes, so as to yield the expected benefits (Colombo et al., 2014).

A further experience extracted from this example is that PBL can be used for training in technical courses. A limitation highlighted in this example is that the marking and assessment of learning required a great deal of organisation and planning.

\subsection{The Food and Culture. Global, Collaborative Classrooms Project}

This project focuses on such themes and real-world issues as Environmental Sustainability, Globalisation, Food, Friends \& Family, Climate change and Water. A student has several options, he/she can select 4-6 themes, or select a theme or issue that he/she is interested in and let that theme be the topic for individual research projects and papers. The approach aims to develop a global, collaborative classrooms project, which will provide a context for students to: develop knowledge, skills and habits conducive to excellent health; practice habits of responsible citizenship - locally to globally; develop global competencies by studying "with" the world instead of "about" the world; develop critical $21^{\text {st }}$ century skills; become engaged in a rigorous, relevant and real-world project; engage the knowledge within the disciplines through research, problem solving and application; and learn - as opposed to memorizing then forgetting discrete facts.

The developed framework allows participants maximum flexibility, and can be easily modified to fit the needs of teachers and students depending upon the age of the students, the courses being taught by the teachers, the daily class schedule and most importantly, the individual needs and interests of the students and teachers.

Teams are responsible for developing their own curriculum, based upon and supported by the Project Guidelines, and utilizing online materials and resources. The curriculum can be implemented as a year-long study, as a six to twelve week unit, as a special project devoting a one or two-hour period each week throughout the school year. 
Learners are divided into expert groups or work independently, in pairs, or groups of three, as they pursue an issue or theme about which they are passionate. It is important to note that students, who work "independently", are required to collaborate with someone in another country as well.

The flexibility of the project allows teachers and students to pursue investigations on topics which they are passionate about, with full freedom of creativity $\left(21^{\text {st }}\right.$ Century Schools, 2015). This example evidences that PBL can used in the context of practical projects and multiple topics can be the focus of learning through engagement with other stakeholders. However, a limitation of this approach is that the wide range of issues may make developing a particular focus difficult without the provision of appropriate support infra-structure.

\subsection{The Eco-House at Sheffield Hallam University}

The Eco-House at Sheffield Hallam University is a project where students from across the engineering school came together to build a one-fifth, working scale model, of an eco-house. The implementation of the project reflected considerable interest that exists in the development of new multidisciplinary experiences for engineering undergraduates, and a number of the early activities developed in this area that have a sustainability theme (Graham, 2010).

The project focused on the learning and teaching environment to facilitate the development of sustainability literacy, namely, on application of engineering knowledge to analyse the efficiency and effectiveness of renewable energy systems.

Multi-disciplinary teams included students from a range of disciplines and backgrounds. The project implementation promoted adoption of professional roles, responsibility, and leadership. In addition, the students collaborated to develop holistic and practical solutions through innovation (Young, 2008). As the example demonstrates, PBL can used to demonstrate practical employability skills, in pilot schemes and where inter-disciplinarity is sought. 


\subsection{The Integrated Approaches to Sustainable Development module, University of Manchester}

This case study describes a pilot development at the University of Manchester supported by the Royal Academy of Engineering's Visiting Professors Scheme (VPS). The project was designed to introduce engineering students to sustainable development within a multidisciplinary context. It combines two areas of considerable interest in UK engineering education: contextualizing sustainable development within the curriculum and providing students with a meaningful interdisciplinary experience.

The core idea of the module is to expose students to complex, 'wicked problems' - working with other disciplines on such problems will give them the confidence to work on difficult reallife problems in their lives beyond university. The first pilot phase of the project was rolled out in 2006. Between years 2006 - 2009 students from such departments as Engineering, Chemistry, Computer Science, Mathematics, Physics Geography and Life Sciences have been enrolled in the module.

Multi-disciplinary groups of around 8 students worked in sequence on 5 project scenarios, each operating in a 2-3 week cycle. Each of these projects was carefully designed as a 'sequence of student-centred, contextual, integrated, active, collaborative and reflective learning opportunities'.

Each group was assigned with a dedicated 'facilitator', typically a Post-Doctoral Research Assistant, to support the group working. The facilitators were given two two-hour sessions of training before the commencement of the module, to introduce the project, the PBL model and how to approach group facilitation.

Typical project outputs would be in the form of a report to the local council, a presentation to a scientific committee or an information leaflet for the public. The project scenarios given to the groups are designed to be 'cumulative', such that the students build on their knowledge, experience and skills through the module (Graham, 2010). Thus PBL can used in modules across courses, but the approach is heavily dependent on the facilitator, the choice of the right PBL methods and the implementation of the process. 


\subsection{Action research with the disciplines of building and construction in Plymouth University, UK}

In the frame of the PBL research conducted in Plymouth University, UK, a real-world 'design and build' project for a waterfront development in the city of Plymouth, UK by a regional developer was used. The research aimed to

- Identify the most appropriate areas for improvement in student PBL in sustainable building through the use of learning technologies;

- Determine the most suitable learning technologies to address the previously identified areas for improvement and how such technologies can add value and be most effectively incorporated into the PBL;

- Develop a sub-site of the university's SharePoint environment, incorporating the use of the identified learning technologies, for optimising student PBL; and

- Evaluate the effectiveness of incorporating learning technology in PBL in sustainable building.

The project was a 'brown-field' development i.e. on a pre-developed site; involving demolition. It required the students to work to the environmental design specifications commensurate with the Building Research Establishment Environmental Assessment Method (BREEAM) 'Excellence' and the Plymouth city's planning requirement for $15 \%$ onsite renewable energy, which together required the most challenging practice in the UK construction industry at the time of this study.

In total, 70 second-year undergraduate students participated in the PBL. They were from five sustainability-embedded building and construction courses: Building Surveying, Construction Management, Environmental Construction Surveying, Architectural Technology, and Architectural Design and Structure.

Three learning modules were involved in the PBL: Technology of Large and Innovative Building; Building Surveying; and Construction Management. This ensured that the PBL was multi-disciplinary. The students worked in groups of five in principle, to cover as many roles in real practice as possible, e.g. architect, structural engineer, services engineer, construction manager, and building surveyor. In addition, each group was allocated an industry mentor (Pan and Garmston, 2012). As this example demonstrates, PBL can be used as a useful learning tool in technical courses; a potential limitation of the approach is that the person delivering the module has to be familiar with PBL methods. 


\section{Discussions and Lessons Learned}

As the paper has outlined, PBL can be an effective approach in implementing principles and practices of sustainability within a learning environment, and can be useful in helping students become more effective problem solvers and professionals.

The concepts of sustainability are gradually permeating most science and engineering disciplines (Duić et al., 2015). Sustainability is closely related to a need for more holistic, integrative and preventative approaches to societal evolution (Alwi et al., 2014). Bearing in mind the usefulness of PBL as a tool towards fostering sustainability, a question which may be asked now is: what are the main lessons learned from the examples provided in this paper?

While there are some limitations on the methods used in this paper in that it represents an analysis of previous documented experiences and does not offer new empirical data since it is not based on any survey instrument, the paper has collated evidence of the ways PBL has been used, in a variety of contexts. The lessons learned can thus, be summarised.

Indeed, the case studies described in this paper illustrate five main trends in relation to the potential of PBL as an example of integrative approaches to foster sustainability, especially in higher education contexts.

Trend 1 - Thematic flexibility: PBL is very flexible and can cater for different themes, focus and context. As seen in the examples provided in this section, it can be used for industrybased projects, the teaching of technical subjects, or as instrument to foster awareness on the links between sustainable development and education.

Trend 2 - Multi-stakeholder use: PBL is not only of interest and use to students and teachers. On the contrary, it can link groups as diverse as students/academics with community groups, farmers, industrialists and other stakeholders. This characteristic makes it of especial interest to areas of studies (e.g. social sciences) where a wide range of actors may be involved.

Trend 3 - Action-orientation: unlike most traditional teaching methods used, where the transmission of knowledge is the goal, PBL schemes can lead to actual changes and improvements. More often than not, PBL projects identify appropriate areas where action is needed, and where changes are needed, be it in respect of infra-structure, thematic focus on even in policy-making. 
Trend 4 - Problem-solving approach to learning: due to its nature, PBL activities are bound to give rise to problems, which need to be addressed as part of the learning process. This valuable feature means that learners become familiar with confronting problems, many of which can be found in the real world. In addition, they also develop the skills to handle (or solve) them.

Trend 5 - Valuable skills development: during the process students have the opportunity to develop 'sustainability literacy' (Stibbe, 2009) and a variety of skills, that will be valued by future employers, including team working, problem solving, project management, research skills and inter-personal competence.

However, it is also important to note a caveat: the successful implementation of PBL is dependent upon careful preparation; the amount of planning required should not be overlooked. The success of the approach will be influenced by a number of factors including the appropriate selection of project themes and the extent to which the appropriate support infra-structure and sub-structures, are in place. Sufficient pre-planning will optimise effectiveness, with flexibility built in to accommodate any unforeseen circumstances that may arise. Although unpredicted circumstances may be problematic, they too, provide students with preparation for work where outcomes will also be uncertain.

At the start, every student should be assigned a duty according to his or her own ability when projects are presented. Students may need some support in understanding the dynamics of team work. Moreover, the availability of tools used in a project and the time to be allocated should be planned carefully, both when preparing projects and teaching is going on (Ergül and Kargın, 2014). In addition, effective goal setting, teaching student project management skills, effective project consultation and monitoring and effective feedback contribute to the effective use of PBL (Garrison, 1999).

Overall, a project based learning approach can cover a wide variety of themes and contexts, which makes it a valuable method, suitable to teachers from any discipline. It offers a unique platform for interaction and for learners to connect, offering a fertile ground for knowledge sharing and learning.

\section{Conclusions}

The features of PBL have been explored in this paper and it has been suggested that PBL is a valuable pedagogic approach in relation to sustainability projects. Providing careful 
consideration is given to the selection of suitable projects, with appropriate support provided for learners, the pedagogic approach has the potential to yield more sustainable and innovative solutions while also enhancing the knowledge and skills of participants. Learning through experience, in real world scenarios, enables the development of competences that will not only be valued in the workplace but will be vital, if the world is to rectify unsustainable development. Such projects will enhance sustainability literacy and when deployed on campus, are likely to also contribute to institutional learning and more integrative approaches to sustainability. They exemplify an experience for the learner where the curriculum, the extra-curricular and the co-curricular, are more effectively entwined and where multidisciplinary perspectives contribute to taking forward sustainable development.

The value of this paper lies within the provision of selected examples of successful approaches to PBL, the identification of themes and the teasing out of the variables favourable to oriented learning that need consideration. The paper provides a basis for others to consider the application of the approach in the context of education for sustainable development. The limitations of the paper are methodological: examples were selected on the basis of convenience and for their illustrative value, rather than through empirical data obtained through the scientific method. Nevertheless, a broad range of initiatives have been drawn together to provide a useful starting point. The conceptual challenge for academics in the future is to design an inter-disciplinary curriculum in such a way that it enables knowledge to be applied in pursuit of sustainability projects while also honing employability skills. Implemented carefully within the university context, students will benefit from hands-on experience with sustainability, the university may also benefit from students' work and a bridge is created between education and professional practice. Future research needs to develop tangible measures to evaluate the impact of such approaches and explore the potential for projects within the curriculum to result in outputs that benefit wider communities 


\section{References}

21st Century Schools, 2015. Food and Culture. A Global, Collaborative Classrooms Project. Available at: http://21stcenturyschools.weebly.com/ [Accessed August 28, 2015].

AASHE, 2010. Sustainability Curriculum in Higher Education: A Call to Action, AASHE (Association for the Advancement of Sustainability in Higher Education), Denver.

Alshuwaikhat, H. M., Abubakar, I., 2008. An integrated approach to achieving campus sustainability: assessment of the current campus environmental management practices. Journal of Cleaner Production, 16, 1777-1785.

Alwi, S. R. W., Manan, Z. A., Klemeš, J. J. Huisingh, D., 2014. Sustainability engineering for the future. Journal of Cleaner Production, 71, 1-10.

Barth, M., and Rieckmann, M., 2012. Academic staff development as a catalyst for curriculum change towards education for sustainable development: an output perspective. Journal of Cleaner Production, 26, 28-36.

Baş, G. \& Beyhan, Ö., 2010. Investigating the effects of project-based learning on students' academic achievement and attitudes towards English lesson. International Electronic Journal of Elementary Education, 2(3), 365-386. Available at: https://www.pegem.net/dosyalar/dokuman/138512-20140104172114-3.pdf.

Bell, S., 2010. Project-Based Learning for the 21st Century: Skills for the Future. The Clearing House, 83(2), 39-43. Available at: http://dx.doi.org/10.1080/00098650903505415.

Biedenweg K, Monroe M.C., Oxarart A., 2013. The importance of teaching ethics of sustainability. International Journal of Sustainability in Higher Education, 14(1), 6-14.

Boaler, J., 1999. Participation, knowledge, and beliefs: A community perspective on mathematics learning. Educational Studies in Mathematics, 40(3), 259-281. Available at: http://link.springer.com/article/10.1023/A:1003880012282.

Bourn, D., Shiel, C. 2009. Global perspectives: aligning agendas. Environmental education Research, 15, 661-677.

Boutou, A., 2013. Sustainability in Higher Education. Benefits and career prospects with an interdisciplinary higher education degree. Master Thesis in Environmental Studies and Sustainability Science, LUCSUS, Lund University, Sweden.

Brinkhurst, M., Rose, P., Maurice, G., Ackerman, J. D., 2011. Achieving campus sustainability: top-down, bottom-up or neither? International Journal of Sustainability in Higher Education, 12(4), 338-354.

Buck Institute for Education (BIE), 2015. Why Project Based Learning (PBL)? Available at: http://bie.org/about/why_pbl [Accessed August 24, 2015].

Centre for Teaching Excellence pf the Singapore Management University, 2015. Instructional Strategies - Project-Based Learning. Available at: http://cte.smu.edu.sg/assurancelearning/integrated-design/instructional-strategies/pjbl [Accessed August 24, 2015]. 
Colombo, C.R. et al., 2014. Active Learning Based Sustainability Education: a Case Study, Available at: http://repositorium.sdum.uminho.pt/bitstream/1822/30173/1/paee2014_submission_55. pdf.

Cortese, A. D., 2003. The critical role of higher education in creating a sustainable future. Planning for higher education, 31 (3), 15-22.

David, J. L., 2008. What Research Says About Project-Based Learning Educational Leadership, 65(5), 80-82. Available at: http://www.ascd.org/publications/educational_leadership/feb08/vol65/num05/ProjectBased_Learning.aspx [Accessed August 24, 2015].

Disterheft, A., Azeiteiro, U. M., Leal Filho, Walter, Caeiro, S. S., (2015). Participatory processes in sustainable universities - what to assess? International Journal of Sustainability in Higher Education, 16(5). doi: 10.1108/IJSHE-05-2014-0079

Dlouhá, J., Barton, A., Janoušková, S., Dlouhý, J., 2013. Social learning indicators in sustainability-oriented regional learning networks. Journal of Cleaner Production, 49(0), 64-73. doi: http://dx.doi.org/10.1016/j.jclepro.2012.07.023

Duić, N., Urbaniec, K. Huisingh, D., 2015. The concepts of sustainability are gradually permeating most science and engineering disciplines. Journal of Cleaner Production $88,1-12$.

Ebner, M., Llenhardt, C., Rohs, M., Meyxer, I. 2010. Microblogs in Higher Education - A chance to facilitate informal and process-oriented learning? Computers \& Education 55, 92100.

Edutopia, 2008. Why Teach with Project-Based Learning?: Providing Students With a WellRounded Classroom Experience. Available at: http://www.edutopia.org/project-learningintroduction [Accessed August 24, 2015].

Efstratia, D., 2014. Experiential education through project based learning. Procedia - Social and Behavioral Sciences, 152, 1256-1260. Available at: http://dx.doi.org/10.1016/j.sbspro.2014.09.362.

Ergül, N.R. \& Kargın, E.K., 2014. The Effect of Project based Learning on Students' Science Success. Procedia - Social and Behavioral Sciences, 136, 537-541. Available at: http://www.sciencedirect.com/science/article/pii/S187704281403852X.

Feletti, G. (1993) Inquiry based and problem based learning: How similar are these approaches to nursing and medical education? In Higher Education Research and Development, 12 (2), 143-156.

Fernandes, S.R.G., 2014. Preparing Graduates for Professional Practice: Findings from a Case Study of Project-based Learning (PBL). Procedia - Social and Behavioral Sciences, 139, 219-226. Available at: http://linkinghub.elsevier.com/retrieve/pii/S1877042814047181.

Gandhi, N., Selladurai, V., Santhi, P., 2006. Unsustainable development to sustainable development: a conceptual model. Management of Environmental Quality: An International Journal, 17(6), 654-672. 
Garrison, J., 1999. John Dewey's Theory of Practical Reasoning. Educational Philosophy and Theory, 31(3), 291-312. Available at: http://onlinelibrary.wiley.com/doi/10.1111/j.14695812.1999.tb00467.x/abstract.

Graham, R., 2010. UK Approaches to Engineering Project-Based Learning, Available at: http://web.mit.edu/gordonelp/ukpjblwhitepaper.pdf.

Gültekin, M., 2005. The Effect of Project Based Learning on Learning Outcomes in the FifthGrade Science Education. Educational Sciences: Theory \& Practice, 5(2), 548-556.

Hadim, H.A., Esche, S.K., 2002. Enhancing the engineering curriculum through project-based learning. Frontiers in Education, 2, F3F-1-6. Available at: http://ieeexplore.ieee.org/stamp/stamp.jsp?tp=\&arnumber=1158200\&isnumber=24586.

Harvey, L., Locke, W., Morey, A. 2002 Enhancing Employability, Recognising Diversity: Making links between higher education and the world of work. London: Universities UK and the Careers Services Unit.

Hmelo-Silver, C.E., Barrows, H.S., 2006. Goals and Strategies of a Problem-based Learning Facilitator. Interdisciplinary Journal of Problem-based Learning, 1(1), 5-22. Available at: http://docs.lib.purdue.edu/ijpbl/vol1/iss1/4/.

Hmelo-Silver, C.E., 2004. Problem-Based Learning: What and How Do Students Learn? Educational Psychology Review, 16(3), 235-266. Available at: http://link.springer.com/article/10.1023\%2FB\%3AEDPR.0000034022.16470.f3\#.

Institute for Teaching and Learning Innovation of the University of Queensland, 2015. Active learning pedagogies. Available at: http://www.uq.edu.au/teach/flippedclassroom/project-bl.html [Accessed August 24, 2015].

Klegeris, A., Hurren, H. 2011. Impact of problem-based learning in a large classroom setting: student perception and problem-solving skills. Advances in Physiology Education, 35(4), 408-415.

Knight, P., Yorke, M. 2003. Assessment, Learning and Employability. London: Society for Research into Higher Education and Open University Press.

Kolmos, A. (1996) Reflections on project work and problem-based learning. European Journal of Engineering Education, 21 (2), 141-148.

Krizek, K. J., Newport, D., White, J., Townsend, A. R. 2012. Higher education's sustainability imperative: how to practically respond? International Journal of Sustainability in Higher Education, 13(1), 19-33.

Kumar, A., 2007. Personal, Academic and Career Development in Higher Education SOARing to Success. London \& New York: Routledge, Taylor and Francis.

Kyndt, E., Dochy, F., \& Nijs, H. (2009). Learning conditions for non-formal and informal workplace learning. Journal for Workplace Learning, 21(5), 369-383.

Lasauskiene, J., Rauduvaite, A., 2015. Project-Based Learning at University: Teaching Experiences of Lecturers. Procedia - Social and Behavioral Sciences, 197(February), 788-792. Available at: http://linkinghub.elsevier.com/retrieve/pii/S187704281504183X. 
Leal Filho, W., Shiel, C., Paço, A., 2015. Integrative approaches to environmental sustainability at universities: an overview of challenges and priorities. Journal of Integrative Environmental Sciences, 12(1), 1-14. DOI: 10.1080/1943815X.2014.988273.

Lee, J.S. et al., 2014. Taking a Leap of Faith: Redefining Teaching and Learning in Higher Education through Project- Based Learning. The Interdisciplinary Journal of Problembased Learning, 8(2), 3-13. Available at: http://docs.lib.purdue.edu/cgi/viewcontent.cgi?article=1426\&context=ijpbl.

Marcos, O. et al., 2015. Project based learning in international context in sustainability and global economy. Time European summer school: a truly European learning experience. In INTED2015 Proceedings, 4266-4279. Available at: http://library.iated.org/view/ORTIZMARCOS2015PRO.

Martinez, F., Herrero, L.C., de Pablo, S., 2011. Project-Based Learning and Rubrics in the Teaching of Power Supplies and Photovoltaic Electricity. Education, IEEE Transactions on, 54(1), 87-96. Available at: http://ieeexplore.ieee.org/stamp/stamp.jsp?tp=\&arnumber=5438911\&isnumber=570562 0 .

Moesby, E. 2005. Curriculum Development for Project-Oriented and Problem-Based Learning (POPBL) with Emphasis on Personal Skills and Abilities. In Global J. of Engineering Education, 9 (2), pp. 12-128.

Pan, W., Garmston, H., 2012. Enhancing Project-Based Learning in Sustainable Building by Incorporating Learning Technology. In 48th ASC Annual International Conference Proceedings. Associated Schools of Construction. Available at: http://ascpro.ascweb.org/chair/paper/CEUE220002012.pdf.

Pavelich, M.J. et al (1995) Real-world problem solving in Freshman Sophomore Engineering. New Directions for Teaching and Learning, 61, 45-54.

Pearson S., Honeywood S., O'Toole M., 2005. Not yet learning for sustainability: the challenge of environmental education in a university. International Research in Geographical and Environmental Education, 14(3), 173-186, DOI: 10.1080/10382040508668349.

Pegg, A., Waldock, J., Hendy-Isaac, S., Lawton, R. (2012). Pedagogy for Employability. York, UK: Higher Education Academy.

Ravitz, J., 2008. Project Based Learning as a Catalyst in Reforming High Schools. American Educational Research Association, pp. 1-14. Available at: http://files.eric.ed.gov/fulltext/ED540113.pdf.

Rodriguez, J. et al., 2015. Project Based Learning experiences in the space engineering education at Technical University of Madrid. Advances in Space Research, 56, pp.1319-1330.

Available

at: http://linkinghub.elsevier.com/retrieve/pii/S0273117715004834.

Scapens, R. W. 1990. Researching Management Accounting practice: The Role of Case Study Methods, British Accounting Review, 22, pp259-281

Shiel C, Paço A., 2012. Do formal policies for sustainable development make a difference? A comparison of students from two different universities, one in the UK and one in 
Portugal. In Leal Filho, W (Ed.) Sustainable Development at Universities: New Horizons. Peter Lang Scientific Publishers, Frankfurt, pp. 575-585.

Shiel C, Williams, A., Mann, S., 2005. Global Perspectives and Sustainable Development in the Curriculum: Enhanced Employability, More Thoughtful Society? In Enhancing Graduate Employability: The roles of learning, teaching, research and knowledge transfer, Proceedings of the Bournemouth University Learning and Teaching Conference, Bournemouth, Bournemouth University, pp.2-16.

Springett, D., 2005. Education for Sustainability' in the Business Studies Curriculum: a Call for a Critical Agenda, Business Strategy and the Environment, 14, 146-159.

Steinemann, A., 2003. Implementing sustainable development through problem-based learning: Pedagogy and practice. Journal of Professional Issues in Engineering Education and Practice, 129(4), 216-224.

Sterling, S., 2004. Higher education, sustainability, and the role of systemic learning, In Higher Education and the Challenge of Sustainability: Problematics, Promise, and Practice, P.B. Corcoran and A.E.J. Wals (Eds), Kluwer Academic Publishers: Dordrecht. p. 4770.

Sterling, S. and Thomas; I. 2006. Education for sustainability: the role of capabilities in guiding university curricula. International Journal of Innovation and Sustainable Development, 1(4), 349-370.

Stibbe, A. (Ed.) 2009. The Handbook of Sustainability Literacy: skills for a changing world. Dartington: Green Books

T.I.M.E European Summer School Consortium, 2015. T.I.M.E European Summer School: Sustainability and the Global Economy. Available at: http://www.time-tess.eu/ [Accessed August 28, 2015].

Tascl, B.G., 2015. Project Based Learning from Elementary School to College, Tool: Architecture. Procedia - Social and Behavioral Sciences, 186, 770-775. Available at: http://linkinghub.elsevier.com/retrieve/pii/S1877042815023903.

Thomas, J. W., 2000. A review of research on project-based learning, Available at: http://bie.org/images/uploads/general/9d06758fd346969cb63653d00dca55c0.pdf.

Voronchenko, T., Klimenko, T., Kostina, I., 2015. Learning to Live in a Global World: ProjectBased Learning in Multicultural Student Groups as a Pedagogy of Tolerance Strategy. Procedia - Social and Behavioral Sciences, 191, 1489-1495. Available at: http://linkinghub.elsevier.com/retrieve/pii/S1877042815027329.

Wade B. H., Stone J. H., 2010. Overcoming disciplinary and institutional barriers: An interdisciplinary course in economic and sociological perspectives on health issues. Journal of Economic Education, 41, 71-84.

Wood, D. F. 2003. ABC of learning and teaching in medicine: problem-based learning. BMJ, $326,328-330$.

Yin, R. K. 1994. Case Study Research: Design and Methods, Beverly Hills: Sage. 
Yorke, M., 2006. Employability in higher education: what it is - what it is not. Learning and Employability Series One. York: ESECT and HEA. Available from: http://www.heacademy.ac.uk/assets/York/documents/ourwork/tla/employability/id116_ employability_in_higher_education_336.pdf [13 February 2012].

Yorke, M. and Knight, P.T. (2004, reissued 2006) Embedding Employability into the Curriculum. York: The Higher Education Academy. Available from:www.heacademy.ac.uk/resources.asp?process=full_record\&section=generic\&id=3 38 (March 2016).

Young, A.E., 2008. An "eco-house" learning and teaching environment to facilitate the development of sustainability literacy. Available at: http://wwwnew1.heacademy.ac.uk/assets/documents/sustainability/andy_young.pdf. 